\section{Marcin Trepczyński}

University of Warsaw

m.trepczynski@uw.edu.pl

ORCID: 0000-0003-0612-2597

DOI: http://dx.doi.org/10.12775/BPTh.2018.016
Biblica

et

Patristica

Thoruniensia

11 (2018) 3: 331-344

ISSN (print) 1689-5150

ISSN (online) 2450-7059

\title{
Aquinas's Exegesis of Ps. 51(50) as a Tool of Christian Education
}

\section{Ezegeza Ps 51(50) św. Tomasza z Akwinu jako narządzie edukacji chrześcijańskiej}

\begin{abstract}
The main hypothesis presented and examined in this paper is that St. Thomas Aquinas had written the commentary on Ps. 51(50) ("Have mercy on me, o God", miserere mei, Deus) mainly for educational reasons. It is argued that he did it not only to collect useful notes to teach about the Psalm's content and understanding, but also, above all, to have a well-designed tool to teach Christian theology. This argumentation is based on external (context) and internal (content) analysis of Ps. 50 conducted in this article. It is also shown that this hypothesis has an additional explanatory power, as it helps us to understand the strategy adopted by Aquinas when composing the commentary and sheds some light on his pedagogical practice.
\end{abstract}

Streszczenie. W artykule zaprezentowano i rozważono hipotezę, zgodnie z którą św. Tomasz z Akwinu napisał komentarz do Ps 51(50) („Zmiłuj się nade mną, Boże”, miserere mei, Deus), mając na względzie cele edukacyjne. Argumentuje się, że nie uczynił tego jedynie, aby zebrać przydatne notatki do nauczania treści i rozumienia owego psalmu, lecz przede wszystkim, by dysponować dobrze zaprojektowanym narzędziem do nauczania teologii chrześcijańskiej. Argumentacja ta opiera się na analizie kontekstu tego dzieła (zewnętrznej) oraz analizie jego zawartości (wewnętrznej). Pokazano również, że hipoteza ta ma walory wyjaśniające, gdyż pomaga zrozumieć przyjętą przez Akwinatę strategię komponowania komentarza, a także rzuca dodatkowe światło na jego praktykę edukacyjną.

Keywords: Ps. 50; Psalm 50; psalms; Thomas Aquinas; Christian education; theology; the Bible.

Słowa kluczowe: Ps 50; psalm 50; psalmy; Tomasz z Akwinu; edukacja chrześcijańska; teologia; Biblia. 


\section{Introduction}

Tn the last period of his life Thomas Aquinas decided to comment on one Lof the most inspiring and important Biblical texts for the Church and its liturgy, namely the Psalms. He composed commentaries on the first 54 Psalms out of 150. One of them is the commentary on the famous Ps. 51(50) being a prayer for mercy by king David who realised that he sinned against God when he committed adultery with Bathsheba and ordered to put her husband Uriah to death in battle (cf. 2 Sam 11:2-12:17).

Of course, this Psalm plays a special role because it refers to this important Biblical story. But what is more, as Aquinas mentions, it closes the set of the first 50 Psalms which are devoted to penitence. Let us note that according to the original text the number of this Psalm is 51, but in Latin versions some Psalms were combined or divided and for this reason St. Thomas knew this Psalm as Ps. 50. In order to be in harmony with Aquinas's text, hereafter I will use this Latin numbering, especially taking into account that this number is meaningful for him, as 50 signifies a Jubilee, so an occasion to remit sins. Addressing such a dramatic situation and being both the final penitential and a "Jubilee" Psalm, David's prayer shows accurately and deeply man's experience of penitence and of obtaining the remission of sins. These are only the major reasons why it is worth analysing how Aquinas commented on this Biblical text in which powerful king cries, "Have mercy on me, o God" (miserere mei, Deus). But Aquinas's commentary on this Psalm is interesting also because of a strategy he adopted here and the conclusions which can be drawn from an analysis of this strategy.

While commenting on Ps. 50 St. Thomas Aquinas had to make many decisions. He needed to plan how he should organise his commentary, how much he should repeat other authors, how many of his own remarks should be included in his text and which information to point out. In order to adopt such a strategy it is very important to define the purpose of the commentary. I will argue that Aquinas was convinced what he wanted to achieve. I will also present the arguments for a hypothesis according to which St. Thomas wrote the commentary on Ps. 50 mainly for educational reasons, not only to have useful notes to teach about the Psalm's content and understanding, but also to have a tool to teach Christian theology.

In my opinion, this task has a great hermeneutical significance. I assume that for a better understanding of the text it is crucial to consider the aim defined by the author. 


\section{Aquinas's strategy}

At the beginning it is worth collecting the most important remarks concerning the mentioned strategy. Aquinas decided to comment on Ps. 50 in the same way as he did when commenting on other Psalms, namely he provided some general information about the text (in this case he underlines the meaning of the number 50 , symbolising - as it has been already said - the Jubilee as an occasion to remit sins, which thus corresponds with the topic of the Psalm); he presented a structure of the Psalm (the so-called divisio textus); and then he commented on the following passages of the Psalm from the title to the end, addressing different meanings of the Scriptures, according to the method he had described before in q. 1 a. 10 of the first part of the Summa Theologiae (hereafter, ST). This means that he followed the commentary structure triad: introductio, divisio textus [particularis], expositio ${ }^{14}$ and his general hermeneutical methods.

What is also important is that he decided to reduce, as far as it is possible, references to philosophical and theological texts in favour of numerous quotations from the Bible. In the commentary on Ps. 50 we find only:

- one reference to Boethius' De Trinitate;

- one to Pseudo-Dionysius the Areopagite's De divinis nominibus;

- two references to Augustine's Confessiones and one to De civitate Dei;

- six to the Gloss, which is not the so-called Glossa Ordinaria (which does not contain explanations used by St. Thomas, apart from the information about hyssopus and the remark about plural form de sanguinibus), but the gloss of Peter Lombard on the Psalms, which is a part of the so-called Magna Glossatura or Maior Glossatura. ${ }^{15}$

Let us add that at the same time it contains - as I have counted - 156 references to the passages from the Bible. This shows that Aquinas had chosen to show links within the Bible rather than to engage philosophical and theological tradition which perhaps could also shed some light on the text of the Psalm. This inner "biblical interconnectedness" is coherent with Aquinas's assumption expressed in the prologue to the commentary that the Psalms contain the whole of theology and the whole of Sacred Scripture ${ }^{16}$ and can be treated as

14 Cf. T. Gałuszka, Super Psalmum XXIII. Badania nad Biblia w XIII wieku, pp. 95-101.

15 M.L. Colish, Peter Lombard. 1, p. 156; T. Gałuszka, Super Psalmum XXIII. Badania nad Biblia w XIII wieku, pp. 28-29.

16 Cf. A. Selva, Unopera di San Tommaso ignorata: il Comento ai Salmi, p. 11; P. Roszak, Principios exegéticos de santo Tomás de Aquino, p. 10. 
St. Thomas's attempt to prove this assumption. We should add here after Piotr Roszak that this is also a result of the locum ex loco technique, thus explaining Scripture by itself. ${ }^{17}$ James R. Ginther, referring to the whole commentary on the Psalms, explains this fact by Aquinas's general idea of underlining the divine roots of the Biblical message: "Thomas is signalling a main tenet of his theological outlook, namely that Scripture interprets Scripture. He does not seek to transform the Psalter into a philosophical textbook, but rather seeks to treat it as a source of divine revelation."18

Next, if we look at the quoted authors, we can see that Aquinas invokes only very strong authorities, and what is important: some of those that are quoted most often in the ST. He uses claims both from Boethius and PseudoDionysius to support the thesis that God is the substance of goodness itself and from Augustine to support the theses that: 1) righteous people do not commit sins because of God's mercy and grace, 2) sins concern also little children (as there are some "inordinate movements" in them), 3) each external sacrifice is a sign of an internal sacrifice. Other theses are not anchored in such authorities. Then a question arises whether these theses really needed such a special support. Perhaps St. Thomas was not convinced that they were widely adopted as mainstream theological truths to leave them without additional justification, whereas other theses just did not need it. Of course, we cannot exclude the possibility that when he kept in mind some good references he just decided to use it. At this stage, we should also remember that Aquinas's entire commentary on the Psalms is a reportatio, ${ }^{19}$ probably prepared by Reginald of Piperno, ${ }^{20}$ and intended to be later revised and maybe supplemented again by Reginald and Thomas, something that never happened in the end. Therefore, we should also take into account the possibility that Aquinas planned to add more references later. However, a question appears whether there are really so many points that he could add to this text which is already so densely woven of extremely brief

17 P. Roszak, Dynamika chrystologiczno-partycypacyjna mądrości w świetle „Super Psalmos" św. Tomasza z Akwinu, p. 81; idem, Principios exegéticos de santo Tomás de Aquino, p. 17.

18 J.R. Ginther, The Scholastic Psalms Commentary as a Textbook for Theology, p. 217.

19 Cf. P. Roszak, Święty Tomasz z Akwinu - komentator Psalmów, p. 26; J.R. Ginther, The Scholastic Psalms Commentary as a Textbook for Theology, p. 223.

20 Cf. J.-P. Torrell, Tomasz z Akwinu - człowiek i dzieło, p. 303 [Original title: Initiation à Saint Thomas d'Aquin. In English edition: Saint Thomas Aquinas: the person and his work.] 
explanations and numerous biblical quotations. If not, then we should abandon this last hypothesis.

What is significant, apart from citing Peter Lombard's gloss six times, is that St. Thomas does not mention any other commentary on this Psalm. Hence, there is another question: does this mean that he neglected the exegetical tradition and tried to work out a completely new commentary? Piotr Roszak underlines the fact that he had to take into account the theological heredity of the Fathers and the early medieval theologians and rework it to create a text useful for $13^{\text {th }}$ century Christians; he also recalls the opinion of Martin Morard that Lombard's influence on St. Thomas is so significant that in fact Aquinas's work is a great commentary to Lombard's gloss; and finally he points out that Thomas took into account and addressed in this work commentaries of many distinguished theologians. ${ }^{21}$ The problem can be resolved by noting that through Lombard's gloss he refers to this whole tradition, as, in fact, Lombard based his text on the works of St. Augustine, St. Jerome, Cassiodorus, St. Gregory the Great, Alcuinus of York and others, and, of course, on the former gloss called the Glossa Ordinaria. When Aquinas has recourse to the Gloss to explain the meaning of the phrase "against thee only have I sinned" (tibi solo peccavi) or what hyssopus is, he uses the comments of St. Augustine. We should also keep in mind that in his expositions on the other Psalms he refers directly to the commentary of Augustine, saying for instance: "We can say that David changes times. Augustine solves this objection in a different way..."22 (In Psalmos, super Ps. 21, n. 9), "But he says, In the midst of the Church, which Augustine explains as follows"23 (In Psalmos, super Ps. 21, n. 18). However, it should be noted that a significant disproportion between references to the authors and Biblical quotations is present in each of St. Thomas's commentaries on the psalms. We should also stress that the majority of his commentaries on Ps. 50, which is, in fact, a tissue made of explanations and quotations, is original. The comparison of the quotations from the Bible collected by Lombard and those by Aquinas for every verse of Ps. 50 reveals that Aquinas did not use the passages from the Gloss, so, in fact, he produced an entirely new commentary. To sum up, St. Thomas chooses the most important information delivered by tradition, but does not seem confined much by what was written by earlier authors.

21 P. Roszak, Święty Tomasz z Akwinu - komentator Psalmów, pp. 23-24.

22 "Possumus dicere quod David mutat tempora. Augustinus aliter solvit..."; source of English translation of Aquinas's exposition to the Psalms in all this paper: Aquinas Translation Project, http://www.dhspriory.org/thomas/PsalmsAquinas/index. htm

23 "Sed dicit, in medio Ecclesiae: quod Augustinus sic exponit, dicens primo sic..." 
Finally, it is important to say that within his exegetical strategy for Ps. 50 Aquinas made a decision to analyse several variants of the translations he knew (especially concerning the second part of verse 7). St. Thomas adopted the following reading of this pericope: "and in sins did my mother conceive me" ("Et in peccatis concepit me mater mea"). But after explaining that this passage concerns the relation between Baptism, circumcision and original sin, he said: "Another text has: My mother sustains me" ("Alia littera habet: Alit me mater mea") explaining that this refers to the actual sins which may also concern little children. Finally, he added: "Another text has: My mother brought me forth" ("Alia littera habet: Peperit me mater mea"), showing that it means that the author of these words was born in the state of original sin. Thus it is clear that he decided to provide the reader or the recipient of his commentary with the interpretation for each version of the text.

What should be now analysed is: who that "recipient" is.

\section{Educational approach - external analysis}

Historical research has led to a consensus that St. Thomas prepared the exposition of the Psalms in the last years of his life, shortly before his death in 1274, namely in 1272-1273 in Naples where he was obliged to transform a provincial dominical school into studium generale, and that he was lecturing on the Psalms for the students of this school starting in autumn 1272 or in autumn 1273. ${ }^{24}$ The text recorded by Reginald is either a reportatio from Aquinas's lectures or notes prepared to conduct such a lecture. Therefore, the exposition on the Psalms was prepared for a pedagogical purpose. It thus differs from other types of theological or philosophical texts which had other aims.

This argument is quite probable, albeit not certain. One could assert that Aquinas composed the commentary independently from his teaching duties. In order to hold this, there should be some supporting (although again only probable) arguments. At this stage, they will be "external", not based on the content of the commentary itself.

We should notice that although some earlier works of Aquinas could also have educational purpose, the proper "educational" period in his life starts in autumn of 1265, when the provincial chapter in Anagna forces him to move to Rome (officially: as his "penance for sins") to organise there studium generale and raise the level of teaching. This is the time when after a failed attempt to

24 Cf. J.-P. Torrell, Tomasz z Akwinu - człowiek $i$ dzieło, p. 302; J.R. Ginther, The Scholastic Psalms Commentary as a Textbook for Theology, pp. 216-217. 
give lectures based on his commentary on the Sentences he starts writing the Summa Theologiae. ${ }^{25}$ This is his first real theological textbook intended to be a suitable educational tool, tailored to the students' abilities, as he explicitly expressed in his famous proemio:

Because the doctor of Catholic truth ought not only to teach the proficient, but also to instruct beginners (incipientes) (according to the Apostle: As unto little ones in Christ, I gave you milk to drink, not meat - 1 Corinthians 3: 1-2), we purpose in this book to treat of whatever belongs to the Christian religion, in such a way as may tend to the instruction of beginners. We have considered that students in this doctrine have not seldom been hampered by what they have found written by other authors, partly on account of the multiplication of useless questions, articles, and arguments, partly also because those things that are needful for them to know are not taught according to the order of the subject matter, but according as the plan of the book might require, or the occasion of the argument offer, partly, too, because frequent repetition brought weariness and confusion to the minds of readers. Endeavouring to avoid these and other like faults, we shall try, by God's help, to set forth whatever is included in this sacred doctrine as briefly and clearly as the matter itself may allow.

A kind of tiredness or even anger caused by unsatisfactory teaching materials is clearly visible here. St. Thomas seems to be deeply engaged in his new educational mission. In 1272, after four years spent in Paris, he comes to Naples with a similar mission: to organise a studium generale and to raise the educational level. And it is quite probable that in teaching the Bible he decides to show the students the richness of the Psalms which, as he asserts in the prologue to his exposition, contain the whole of Sacred Scripture. In order to do this well and thoroughly he does not simply use a Gloss, but needs to prepare his own material. This may be the first supporting argument.

Furthermore, James R. Ginther seems to suggest that all Aquinas's activities were complementary: he simultaneously wrote his commentary on the Psalms and the tertia pars of the ST during his morning and afternoon teaching sessions respectively (where he could test his ideas), working on the former text while writing the latter. Ginther observes that

It is not without significance that the commentary of Aquinas came to fruition five years after he had begun his own famous Summa, and indeed he was in the process of writing the tertia pars while he was expounding the Psalms. Perhaps this is why

25 Cf. J.-P. Torrell, Tomasz z Akwinu - człowiek i dzieło, pp. 175-178. 
his commentary is an ideal test case for how a master of the sacred page utilized the Psalms as a textbook for teaching theology. ${ }^{26}$

It seems that such an idea of a fruitful scientist-teacher's economy also supports the argument that the commentary was intended to be used during classes.

Let us finally add another opinion of Ginther for this thesis. Talking about the practice of teaching theology in the $13^{\text {th }}$ century, he points out the educational significance of the Biblical text as the definitive foundation for this process: "contrary to the common view, the textbook for theology was not the Sentences of Lombard, but rather the Bible."27

\section{A tool of Christian education - internal analysis}

Starting the analysis based on the text of the commentary of Ps. 50 let us first make a general and quite obvious remark. If St. Thomas wanted to write a text concerning this Psalm in which he presents some new approach or interpretation in order to communicate it to other theologians (let us call it scientific reasons), he would simply comment on some selected pericopes in order to raise some specific questions, as he did in his exposition of Boethius's De Trinitate, which he planned to be, in fact, a treatise on theology and which he concluded with the insight that we cannot know God's essence (cf. De Trin., pars 3, q. 6, a. 4), and in this way he abandoned Boethius's text which took up further problems; whereas in case of the 54 Psalms commented on by Thomas we find a project of full and exact exposition of all the content, passage by passage in order to present and explain this content. In my opinion, this is the first step in the "internal analysis" to assume "educational reasons" in the background of his work.

The analysis of Aquinas's exegesis of Ps. 50 inclines us also to exclude the possibility that this text was intended to be a sermon or a text aimed at spiritual or moral formation. An example of such a text is the commentary of St. Augustine (Enarrationes in Psalmos, Ps. 50, PL 36, 585-599). Besides the fact that the commentary is called a "sermon", we can easily see in it many rhetorical features, such as repetitions, exclamations, speaking in plural form of the first person ("we"), direct expressions in vocativus like "fratres" (brothers/brethren)

26 J.R. Ginther, The Scholastic Psalms Commentary as a Textbook for Theology, p. 216.

27 J.R. Ginther, The Scholastic Psalms Commentary as a Textbook for Theology, p. 213. 
or "fratres mei" (my brothers/brethren), a series of questions and short answers like: "Quo merito? Medicus est, offer mercedem: Deus est, offer sacrificium. Quid dabis ut munderis? Vide enim quem invoces; iustum invocas: odit peccata, si iustus est; vindicat in peccata, si iustus est; non poteris auferre a Domino Deo iustitiam eius" ( $7 ;$ v. 4$)$, or even sentences addressed directly to the listener like: "Ad te Nathan propheta non est missus, ipse David ad te missus est" (5; v. 1-2). Though it is possible that the text is stylised, it is, however, highly probable that those features indicate its pastoral function. Aquinas's commentary lacks such characteristics and has no formal solutions which would help his listeners if it were used as a sermon.

Now let us present some arguments based on the "internal analysis" which not only support the general thesis that Aquinas's exegesis of Ps. 50 was intended to explain the contents of the Psalms, but also that it was a tool of Christian education.

The main evidence for this hypothesis is the presence of doctrinal remarks in the text of the commentary. The first one concerns two aspects of mercy:

And it must be noted that anyone can hope on divine mercy with a two-fold reason. One reason is from reflection, and according to the multitude of his accomplishments. First, therefore, he shows that he hopes on the mercy of God from reflection on the divine nature, for it is a characteristic of the divine nature that it be goodness itself. Whence Dionysius says that God is the very substance of goodness. And likewise, Boethius On the Trinity. Whence this mercy of God is nothing other than goodness referred to the driving away of wretchedness. ${ }^{28}$

This corresponds with a short remark in Peter Lombard's exposition: "Et est misericordia in natura, miseratio in effectu" (PL 191, 485B). We can see here that Thomas encourages his listeners to go deeper and understand this distinction in the light of a theological truth which was very important to him, namely, that mercy as a divine attribute is, in fact, identical with God's goodness and essence itself. This is one of the crucial theological messages that he wants to teach them, and perhaps this is why he strengthens it by citing two great authorities: Boethius and Pseudo-Dionysius.

28 "Et notandum, quod aliquis potest sperare de misericordia divina, duplici ratione. Una ratio est ex consideratione divinae naturae: alia ratio est ex consideratione et secundum multitudinem effectuum ejus. Primo ergo ostendit quod sperat de misericordia Dei ex consideratione naturae divinae, quia naturae divinae proprium est quod sit ipsa bonitas. Unde Dionysius dicit, quod Deus est ipsa substantia bonitatis. Et Boetius de Trin. similiter. Unde nihil aliud est haec Dei misericordia, nisi bonitas relata ad depellendam miseriam.” 
Another "doctrinal" message can be found in the following passage concerning the effects of sin (referring to Nathan's words to David taken from 2 Sam 12, 13: "The Lord has given thy sin quittance", dominus transtulit peccatum tuum):

There remains however a double effect of sin: that is to say the charge of punishment. ${ }^{29}$

The next example addresses two steps of removing blame:

Two things are necessary for removing a stain, namely, a preceding washing and a following cleanliness. In bodies a washing is made through water, and so, according to the Gloss, the Psalm, through water, prefigures the power of baptism, by which God would be removing sin..$^{30}$

We can also find an example of some doctrinal pairs of oppositions:

iniquity is opposed to justice, but sin to cleanliness. ${ }^{31}$

Another "educational" solution is pointing out a strong Western Christian theological thesis (which for instance in Lombard's exegesis is not explicitly underlined in such a way) referring to the concept of original sin in a very suggestive manner, using words like 'root' (radix) and 'tainted' (infectus):

The root of all actual guilt is original sin which is contracted from parents tainted with that $\sin .{ }^{32}$

Later Aquinas adds another message strengthened by the introductory phrase "it must be known" (sciendum est), concerning original sin:

For it must be known that man, through sin, first incurs uncleanness. ${ }^{33}$

29 "Remanet autem duplex effectus peccati: scilicet reatus poenae, et macula in anima. Primo ergo petit removeri reatum poenae."

30 "Duo sunt necessaria ad removendum maculam: scilicet ablutio praecedens, et munditia sequens. In corporibus ablutio fit per aquam, et sic secundum Glossam Psalmus per aquam praefigurat virtutem Baptismi, qua Deus dimissurus erat peccatum."

31 "iniquitas est contraria justitiae; peccatum vero munditiae."

32 "Radix omnis culpae actualis est peccatum originale, quod a parentibus contrahitur infectis illo peccato."

33 "Sciendum est autem, quod homo per peccatum primo incurrit immunditiam." 
We can record also other doctrinal messages. Let us list them here:

it must be known that spiritual joy has three steps. The first is manifest in the conciliation of desire; the second in the enlarging of the heart; the third in advancing to outward things; ${ }^{34}$

[...] grace is declared the benevolence of God, by which God loves man unto eternal life. And as far as anything is concerned, it is dissimilar. For the grace of man does not make him good, but out of its goodness one is made pleasing to man; but with God, it is in a contrary manner: for from the benevolence of God it follows that man should be made good. Therefore there are two things in the grace of God; namely, benevolence itself and its effects on the soul; ${ }^{35}$

[...] the gift of grace is given through charity, and such a gift is given through the Holy Spirit; ${ }^{36}$

[...] for he who has grace has charity; and he who has charity loves God, and possesses him; and he who has what he loves, rejoices. Therefore, where charity is, there is joy; ${ }^{37}$

[...] for a lower power is not enough to show help against a higher (...) Therefore against the devil man needs to be helped by a perfect spirit, that is, one ruling and prevailing over all things; $; 8$

[...] It must be noted that in this reading there is made a triple mention of spirit: it is called a right spirit, a holy spirit and a perfect spirit; ${ }^{39}$

34 "sciendum est, quod spirituale gaudium habet tres gradus. Primo existit in complacentia affectus; secundo in dilatatione cordis; tertio in progressu ad exteriora."

35 "gratia dicitur benevolentia Dei, qua Deus diligit hominem ad vitam aeternam. Et quantum ad aliquid est dissimile: gratia enim hominis non facit eum bonum, sed ex sua bonitate efficitur gratus homini: sed apud Deum est e converso: quia ex Dei benevolentia sequitur quod homo fiat bonus. Duo ergo sunt in gratia Dei: scilicet ipsa benevolentia, et effectus ejus in anima."

36 "donum gratiae datur per caritatem: et tale donum datur per spiritum sanctum."

37 "qui habet gratiam, habet caritatem, et qui habet caritatem, amat Deum, et habet ipsum; et qui habet quod amat, gaudet. Ergo ubi caritas, ibi gaudium."

38 "virtus inferior non est sufficiens ad praebendum auxilium contra superiorem [...]. Ergo contra Diabolum indiget homo juvari spiritu principali, scilicet principante et dominante super omnia."

39 "Notandum est quod in hac lectione fit triplex mentio de spiritu: quia dicitur spiritus rectus, spiritus sanctus et spiritus principalis." 
For the Holy Spirit causes three things in man. First, rectitude of purpose. [...] Also, it sanctifies us. (...) Also, it makes us illustrious and makes us princes. [...]. ${ }^{40}$

All of these brief points and distinctions are essential parts of Aquinas's commentary. At the same time his exegesis is an occasion to teach them. In commenting on Ps. 50 Aquinas forms in his students a precise theological understanding concerning such topics as:

- God's essence;

- the concept of mercy;

- blame, sin and removing them;

- original sin;

- spiritual joy and its steps;

- God's good will and its relations with grace and human goodness;

- relations between love, grace and joy;

- practical spiritual consequences of the levels of powers;

- three types of spirit;

- the effects of the Holy Spirit's action on humans.

In this context David's words become a great illustration of these truths, as every student while repeating this Psalm could easily recall them in his memory. To sum up, in my opinion, the content of Aquinas's exposition on Ps. 50 reveals that he intended not only to explain what this Psalm is about (so to deliver a biblical knowledge), but also to use it to teach Christian theology.

In the end, it is worth noting that in Aquinas's commentary on Ps. 50 in addition to theological theses we also find claims belonging rather to the field of psychology such as:

The man who has a well-disposed conscience abhors more the uncleanness of the guilt than the severity of the punishment. ${ }^{41}$

We should also go back to the question concerning the cited authors. If we accept the hypothesis presented here, it can be understandable why Aquinas indicates by name only three authors and makes only five references to their utterances among the great number of Biblical quotations. If it was a basis for a lecture, if the Psalm exegesis was also an occasion to teach theology and if he wanted to efficiently introduce some important authors and their messages

40 "Tria autem facit spiritus sanctus in homine. Primo rectitudinem intentionis [...]. Item sanctificat nos [...]. Item nobilitat et facit nos principes."

41 "Homo qui habet mentem bene dispositam, plus abhorret immunditiam culpae, quam austeritatem poenae." 
(perhaps not well-known to the students in Naples, for sure not so well-known as Biblical passages), he would need to select only a few authors and do it carefully. Otherwise, he could bring "a confusion to the minds of readers", as he noticed in the prologue to $S T$, quoted above.

\section{Conclusions}

Based on the above analysis we can offer the following conclusions:

1. There is a strong basis in the text of Aquinas's commentary on Ps. 50 for recognizing that it was intended not only to explain the Psalm's content and in this way provide biblical knowledge, but to be used as a tool of Christian theological education. St. Thomas was convinced of this and realised his plan. Perhaps we can assume that he had the same strategy while commenting on the other psalms.

2. This hypothesis can be treated as a more specific and focused version of the general thesis that this commentary was written for educational reasons, namely as a reportatio of his lectures or as notes forming the basis for future lectures; this is supported by historical data and some probable arguments built upon them.

3. This "more specific" hypothesis has an additional explanatory power, as it helps us to understand the strategy adopted by Aquinas when composing the commentary and sheds some light on his pedagogical practice. Furthermore, that special purpose, namely to teach Christian theology through the Psalms, is an additional point in the discussion on the originality of this text.

4. This hypothesis is significantly in harmony with Aquinas's opinion expressed in the prologue to his commentary to the Psalms that the Psalms contain the whole of theology.

\section{References}

Colish M.L., Peter Lombard. 1, Brill 1994.

Gałuszka T., Super Psalmum XXIII. Badania nad Bibliq w XIII wieku, Homini, Kraków 2005.

Ginther J.R., The Scholastic Psalms Commentary as a Textbook for Theology: the Case of Thomas Aquinas, in: Omnia disce: Medieval Studies in Memory of Leonard O. Boyle, OP, ed. A.J. Duggan, J. Greatrex and B. Bolton, Ashgate, Aldershot 2005, pp. 211-229. 
Roszak P., Święty Tomasz z Akwinu - komentator Psalmów, in: Miserere mei, deus. Psalm 50 (51) winterpretacji św. Tomasza z Akwinu, ed. M. Mróz, Wydawnictwo Naukowe UMK, Toruń 2010, pp. 21-40.

Roszak P., Dynamika chrystologiczno-partycypacyjna mądrości w świetle „Super Psalmos" św. Tomasza z Akwinu, Teologia w Polsce, 2: 2013, pp. 79-99.

Roszak P., Principios exegéticos de santo Tomás de Aquino. Claves hermenéuticas para la Lectura super Psalmos, in: Comentario al Libro de los Salmos (números 16 a 27): Santo Tomás de Aquino, Santiago de Chile 2016, pp. 9-27.

Selva A., Un'opera di San Tommaso ignorata: il Comento ai Salmi, Dominicus 2002, 1, pp. 3-12.

Torrell J.-P., Tomasz z Akwinu - człowiek i dzieło, Marek Derewiecki, Instytut Tomistyczny, Kęty-Warszawa 2008. [Original title: Initiation à Saint Thomas d'Aquin. In English edition: Saint Thomas Aquinas: the person and his work.] 